\title{
Margaret McCartney: The government's plan to blame and shame people for having disease
}

\author{
Margaret McCartney general practitioner, Glasgow
}

Carol Black, chair of the health think tank the Nuffield Trust and a government policy adviser, is to conduct a "rapid review." Essentially, the government would like to reduce or stop paying benefits to people who are obese or who have alcohol or drug dependency if they do not comply with treatment. ${ }^{1}$

Although this idea was in the recent Conservative manifesto ("if they refuse a recommended treatment, we will review whether their benefits should be reduced"), ${ }^{2}$ it isn't new. The Labour administration's Welfare Reform Bill of 2009 had a provision requiring Jobcentres to force people who were addicted to drugs and claiming sickness benefit to face benefit sanctions unless they attended "education programmes." ${ }^{\text {"3 }}$ These were not piloted, and the clauses were later dropped.

The government has chosen people with these diseases because, as a group, they are weak. Politicians are inciting taxpayers to become self righteous: by presenting these patients as suspects who may be wilfully unemployed, they are pressing us to seek value from our investment.

This stigmatising is fuelled by a simple judgment-namely, that these are self inflicted illnesses that these patients have chosen. That they have the power to stop it but have chosen not to. And that we taxpayers may then decide that they do not merit our collective support.

But we've had no call to ban people injured in skiing accidents from getting appropriate NHS plaster casts. And, so far at least, a woman who orders too few of her drugs for hypertension is still allowed treatment for her stroke. Judgments are being made on what is and isn't fair access to pooled resources-but they are being made for groups of citizens that are easy for those with power to pick off.

And, I hear you asking, what of the evidence? I cannot locate any trial that found that disincentives (withholding sickness benefit unless people "engage" with treatment) have lasting benefit; yet bariatric surgery, the most effective treatment for morbid obesity, is briskly rationed nationwide.

The concept of forcing people to engage with treatment is at first laughable but then bewilderingly unethical: healthcare professionals are bound by our regulators, such as the General Medical Council, not to coerce people into treatment. Yet we already have the Department for Work and Pensions placing psychologists in Jobcentres ${ }^{4}$ despite this not having been shown to improve the chances of permanent paid work-and "clearly raising ethical questions." 5

The idea in all of this is to cement a view that something intrinsic to unemployed people prevents them from getting a job-as if the offer of a zero hours, below minimum wage contract is a problem that can be solved through psychological help for the would-be employee.

What of the children of patients with obesity or drug dependency who are likely to be pushed further into poverty, through no fault of their own, if this plan goes ahead? We all have personal responsibility for our actions. But we should not destroy collective responsibility for public health and fair law by publicly shaming people or by coercing them to accept ineffective medicine.

Competing interests: I have read and understood the BMJ policy on declaration of interests and declare the following interests: I'm an NHS GP partner, with income partly dependent on Quality and Outcomes Framework points. I'm a part time undergraduate tutor at the University of Glasgow. I've written two books and earn from broadcast and written freelance journalism. I'm an unpaid patron of Healthwatch. I make a monthly donation to Keep Our NHS Public. I'm a member of Medact. I'm occasionally paid for time, travel, and accommodation to give talks or have locum fees paid to allow me to give talks but never for any drug or public relations company. I was elected to the national council of the Royal College of General Practitioners in 2013 and am chair of its standing group on overdiagnosis. I have invested a small amount of money in a social enterprise, Who Made Your Pants?

Provenance and peer review: Commissioned; not externally peer reviewed.

Follow Margaret on Twitter, @mgtmccartney

Department for Work and Pensions. An independent review into the impact on employment outcomes of drug or alcohol addiction, and obesity: call for evidence. July 2015. www. gov.uk/government/uploads/system/uploads/attachment data/file/448830/employmentoutcomes-drug-alcohol-obesity--independent-review.pdf.

outcomes-drug-alcohol-obesity--independent-review.pdf.
Conservative Party. Manifesto 2015. April 2015. www.conservatives.com/manifesto.

3 DrugScope. Bitesized briefing: welfare reform - what's going on? 2011. www.drugscope. org.uk/Resources/Drugscope/Documents/PDF/Policy/BBWelfareReformWhatsGoingOn pd 
4 Department of Health. Response to Freedom of Information Act request. 5 May 2015. www.whatdotheyknow.com/request/262777/response/648730/attach/html/2/Response\% 20to\%20931847.pdf.html.

5 Friedli L, Stearn R. Positive affect as coercive strategy: conditionality, activation and the role of psychology in UK government workfare programmes. Med Humanit 2015;41:40-7.
Cite this as: BMJ 2015;351:h4368

๑ BMJ Publishing Group Ltd 2015 